\title{
Colonial Nesting Bird Survey on the Bureau of Land Management Lewistown District: 1996
}

\author{
A Report to: \\ Bureau of Land Management \\ Lewistown District \\ 80 Airport Road \\ Lewistown, MT 59457 \\ Submitted by: \\ H. Peter Feigley \\ March 1997
Montana Natural Heritage Program 1515 East Sixth Avenue
P.O. Box 201800
Helena, MT 59620-1800




\section{Montana Natural Heritage Program}

This document should be cited as follows:

Feighley, H. P. 1998. Colonial nesting bird survey on the Bureau of Land Management Lewistown District: 1996. Montana Natural Heritage Program. Helena, MT. 27 pp. 


\begin{abstract}
A total of 132 lakes, reservoirs, and ponds were surveyed on the Lewistown District of the Bureau of Land Management. Surveys were conducted by one or two individuals between 3 June and 25 July 1996. The duration of the surveys ranged between $1-180$ person-minutes and consisted of a search of the wetland with binoculars and/or spotting scope for adult birds or nests. If adults were seen, an effort was made to determine 1) numbers present; and 2) breeding status. Nine species of colonial nesting shore- and waterbird were detected: American White Pelican (Pelecanus erythrorhynchos), Black-crowned Night-Heron (Nycticorax nycitorax), Doublecrested Cormorant (Phalacrocorax auritus), Black Tern (Chlidonias niger), Common Tern (Sterna hirundo), Forster's Tern (Sterna forsteri), California Gull (Larus californicus), Franklin's Gull (Larus pipixcan ), and Ring-billed Gull (Larus delawarensis). All, but American White Pelican and Franklin's Gull, were documented as breeding or probable breeding at one or more sites. Verified or probable nesting by 1 or more species of colonial waterbird was identified at 19 (14\%) sites. Breeding colonies of Double Crested Cormorant, Black-crowned Night-Heron and California Gull were found at only one site each. Breeding or probable breeding colonies at multiple sites were recorded for Ring-billed Gull (4 sites), Common Tern ( 7 sites), Forster's Tern (5 sites) and Black Tern (5 sites). Most (68\%) occupied sites were larger than 100 acres, with only one less than 30 acres. Pooled 1995 and 1996 survey data indicated that colonial nesters tended to be associated with larger sites ( $>40$ acres). Seventy-eight percent of occupied sites had emergent vegetation along more than $25 \%$ of the shoreline and permanent bodies of water accounted for $83 \%$ of the occupied sites.

Other TES or "watch-list" bird species encountered during the surveys were Common Loon (Gavia immer), Loggerhead Shrike (Lanius ludovicianus), Baird's Sparrow (Ammodramus bairdii) and Peregrine Falcon (Falco peregrinus). In addition, four amphibian and three reptile species were observed: tiger salamander (Ambystoma tigrinum), western chorus frog (Pseudacris triseriata), northern leopard frog (Rana pipiens), plains spadefoot (Scaphiopus bombifrons), painted turtle (Chrysemys picta), western terrestrial garter snake (Thamnophis elegans) and plains garter snake (Thamnophis radix).
\end{abstract}




\section{TABLE OF CONTENTS}

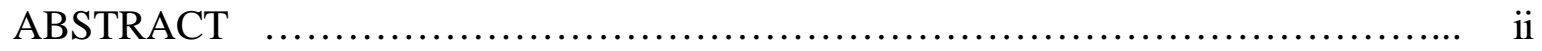

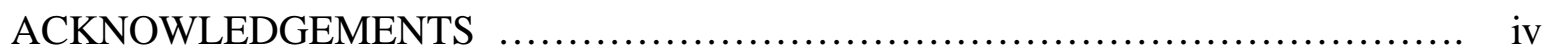

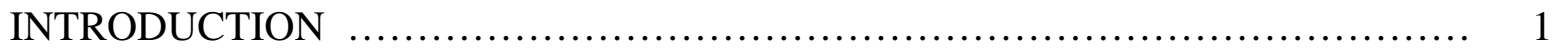

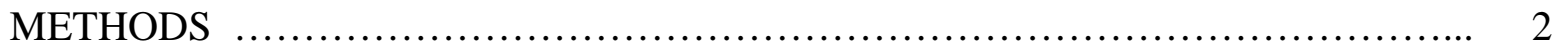

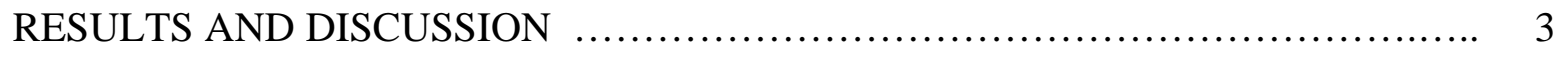

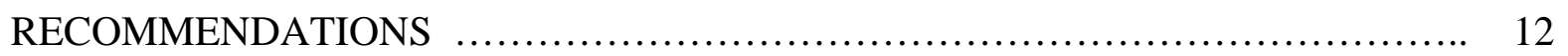

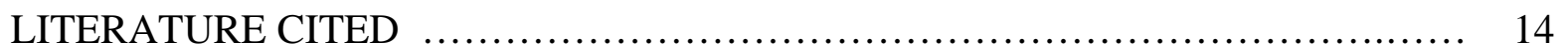

APPENDIX 1. Characteristics of wetland sites surveyed for colonial nesting birds $\ldots . . \quad 15$

APPENDIX 2. Maps of observations of TES colonial nesting birds ( u n a va i la ble) ... 23 


\section{ACKNOWLEDGEMENTS}

Financial support for this project came from the Lewistown District of the Bureau of Land Management and the Montana Natural Heritage Program (Montana State Library, Natural Resource Information System and The Nature Conservancy). Field surveys were conducted by Paul Hendricks and the late Jim Reichel. Jim Reichel had performed the initial synthesis of the data. Cedron Jones, John Hinshaw, Martin Miller and Janice Miller assisted with data entry/management and Map preparation. This report is dedicated to the memory of Jim Reichel, whose expertise, enthusiasm and dedication greatly advanced our knowledge of birds in Montana. 


\section{INTRODUCTION}

Due to the aggregation of nests in relatively small areas, colonial nesting birds are particularly sensitive to disturbance. Disease or man-made and natural disturbances resulting in habitat alterations can devastate colonies of nesting birds. Some species of colonial nesting birds have experienced population declines and/or range reductions (Dunn and Argo 1995, Burger and Gochfeld 1994, Knopf 1994, Evans and Knopf 1993). Because of their sensitivity, many colonial nesting shore- and waterbirds are considered species of special concern by various agencies and programs.

The Montana Natural Heritage Program lists Clarke's Grebe (Aechmophorus clarkii), American White Pelican (Pelecanus erythrorhynchos), White-faced Ibis (Plegadis chihi), Black-crowned Night-Heron (Nycticorax nycitorax), Piping Plover (Charadrius melodus), Black-necked Stilt (Himantopus mexicanus), Franklin's Gull (Larus pipixcan), Caspian Tern (Sterna caspia), Common Tern (Sterna hirundo), Forster's Tern (Sterna forsteri), Least Tern (Sterna antillarum), and Black Tern (Chlidonias niger) as species of special concern in the state. Within the Montana portion of their range the U.S. Fish and Wildlife Service (USFWS) has listed the Piping Plover as Threatened and the Least Tern as Endangered, both of which are loosely colonial nesters. The White-faced Ibis and Black Tern were formerly listed by the USFWS as candidate (C2) species. All of these species are known to, or potentially occur on the Lewistown District of the BLM (LD-BLM).

During 1995 MTNHP surveyed 165 lakes, reservoirs, ponds and river reaches on 10 USGS quads and several miscellaneous larger wetlands on BLM lands on the Lewistown District (Reichel 1996). Black Terns were only found at two locations, both larger wetland areas; i.e., Freezeout Lake (> $1000 \mathrm{ac)}$ ) and "Fifteen-mile Reservoir" (ca. $60 \mathrm{ac}$ ). None of the known Black Tern sites in Montana were smaller than $40 \mathrm{ac}$, though in other areas nesting Black Terns can occur in wetland areas of one or two acres. Other colonial nesters (i.e., Black-Crowned Night Heron, Black -necked Stilts, Franklin's Gull, Caspian Tern, Common Tern, Forster's Tern, Least Tern, and Black Tern) were found nesting only at the Freezeout Lake complex (a large wetland area).

Since most of the sites sampled in 1995 were small, the following survey was conducted on the LD-BLM, focusing on wetland areas larger than 40 acres. The objective of this follow-up survey was to assess the distribution of colonial nesting birds on LD-BLM lands, with emphasis on Montana state species of special concern. Also, the survey results would provide information for decisions on a BLM list of Sensitive Species. Species that are known or likely to occur on the LD-BLM are: Clarke's Grebe, American White Pelican, White-faced Ibis, Black-crowned NightHeron, Black-necked Stilt, Franklin's Gull, Caspian Tern, Common Tern, Forster's Tern, Least Tern, and Black Tern. 


\section{METHODS}

Statewide 1:100,000 scale digital hydrology and land ownership coverages were available at the Montana Natural Resource Information Service (NRIS). The hydrology coverage included all bodies of water down to approximately 10 acres. A geographical information system (GIS) was used to query digital hydrology and land ownership for the LD-BLM and select all wetlands $>40$ acres and occurring on BLM lands. A subset of sites consisting of the largest 20 unsurveyed wetlands and a minimum of 10 sites from each of the five Resource Areas ( Great Falls, Havre, Judith, Phillips and Valley Resource Areas) comprising the LD-BLM was developed. Counties involved in the survey included Blaine, Chouteau, Fergus, Hill, Petroleum, Phillips, Teton, Toole, and Valley.

Visual surveys for colonial nesting waterbirds were conducted between 3 June and 25 July 1996. Length of the survey varied by the size of the site and ranged from 1 - 180 minutes. Locations, behavior suggesting breeding, numbers, and stage of development of young were recorded. For American White Pelicans, Great Blue Herons, Caspian Terns, Common Terns, and Forster's Terns the colony nesting locations were relatively easily observed and populations readily determined from a distance using binoculars/spotting scope to minimize disturbance. For Clark's Grebe, White-faced Ibis, Black-crowned Night-Heron, Franklin's Gull, and Black Tern, the nests were often hidden in dense vegetation. When these species were suspected to be nesting, searches for nests were conducted for up to 1 hour. If a nest was found, breeding was verified and the search ceased; if no nest was found, behavioral clues (defensive behaviors, carrying food or nesting material, etc.) were used to determine probable nesting. Numbers were estimated by observation of adults; if a Black-crowned Night-Heron rookery was suspected, observations resumed at dusk to count adults leaving to feed. Black-necked Stilts, Least Terns, and Piping Plovers have cryptic nests and are sensitive to disturbance; if behavioral clues suggested nesting, then searches for nests were conducted for 30 minutes. If a nest was found, breeding was considered verified and the search ceased; if no nest was found, behavioral clues were used to determine probable nesting. Numbers were estimated by observation of adults.

Habitat of all TES species located was recorded; for marsh/pond/lake locations habitat was recorded for all surveyed locations whether TES species were located or not. Vegetative habitat was recorded on a basic level, such as cattail marsh, bulrush, willow thicket, or sedge meadow, and percent of shoreline with emergent vegetation. Physical factors such as size of wetland, permanence of the water body and origin (natural/ man-made) were documented. Other nontarget colonial nesters, or other TES species encountered, were recorded and mapped. Amphibians and reptiles observed during the surveys were recorded.

Detailed species accounts for TES colonial nesting shore- and waterbirds breeding, or potentially breeding, on the Lewistown District were provided in a previous report (Reichel 1996). These accounts will not be duplicated in this report. 


\section{RESULTS AND DISCUSSION}

A total of 132 lakes, reservoirs, and ponds were surveyed on the Lewistown District of the Bureau of Land Management between 3 June and 25 July 1996 (Figure 1 and Appendix 1). This is in addition to the 165 sites surveyed in 1995. Sixty survey sites were on the Phillips Resource Area, while 17 were on Great Falls, 18 on Havre, 16 on Judith and 21 on Valley Resource Areas. Approximate sizes of the surveyed sites ranged from 0 (i.e., dry sites) to 3207 acres. Half of the survey sites (66) were larger than 40 acres, while 23 of the sites were dry. Temporary bodies of water accounted for 116 sites, while 16 sites were permanent.

Nine species of colonial nesting shore- and waterbird were detected: American White Pelican, Black-crowned Night-Heron, Double-crested Cormorant (Phalacrocorax auritus), Black Tern, Common Tern, Forster's Tern, California Gull (Larus californicus), Franklin's Gull, and Ringbilled Gull (Larus delawarensis). All, but American White Pelican and Franklin's Gull, were documented as breeding or probable breeding at one or more sites (Tables 1 and 2). Verified or probable nesting by 1 or more species of colonial waterbird was identified at $19(14 \%)$ sites. Breeding colonies of Double Crested Cormorant, Black-crowned Night-Heron and California Gull were found at only one site each. Breeding or probable breeding colonies at multiple sites were recorded for Ring-billed Gull (4 sites), Common Tern (7 sites), Forster's Tern (5 sites) and Black Tern (5 sites). (See Appendix 2 for maps of locations of TES colonial shore- and waterbirds observed during the 1996 field surveys.)

All, but one occupied site (7 acres), were larger than 30 acres. Thirteen (68\%) of occupied sites were 100 acres or larger. These data were consistent with the 1995 survey, where no colonial nesters were found on bodies of water smaller than 40 acres (Reichel 1996).

Other TES or "watch-list" bird species encountered during the surveys were Common Loon (Gavia immer), Loggerhead Shrike (Lanius ludovicianus), Baird's Sparrow (Ammodramus bairdii) and Peregrine Falcon (Falco peregrinus) (Table 1). In addition, four amphibian and three reptile species were observed: tiger salamander (Ambystoma tigrinum), western chorus frog (Pseudacris triseriata), northern leopard frog (Rana pipiens), plains spadefoot (Scaphiopus bombifrons), painted turtle (Chrysemys picta), western terrestrial garter snake (Thamnophis elegans) and plains garter snake (Thamnophis radix) (Appendix 1).

\section{General Habitat Relationships}

In an effort to evaluate general habitat relationships for TES colonial nesting shore- and water birds the following variables were examined: number of sites surveyed and occupied, site size (area of water body/ wetland), percent of shoreline with emergent vegetation for sites larger than 5 acres and permanence of the water body for sites larger than 5 acres. Data for TES colonial nesting birds were pooled from the 1995 and 1996 field surveys (Tables 3 - 5). (Note that no additional Black-necked Stilt colonies were identified during the 1996 field surveys.) Since 8 sites were repeats from 1995 and Missouri River reaches were not included, the total number of pooled sites was 269 . There were 127 sites larger than 5 acres for which lake permanence had 


\section{Figure 1.}

Map of survey locations for colonial nesting birds, Lewistown District, BLM, 1995 and 1996 
Surveys for colonial nesting birds, Lewistown District, BLM

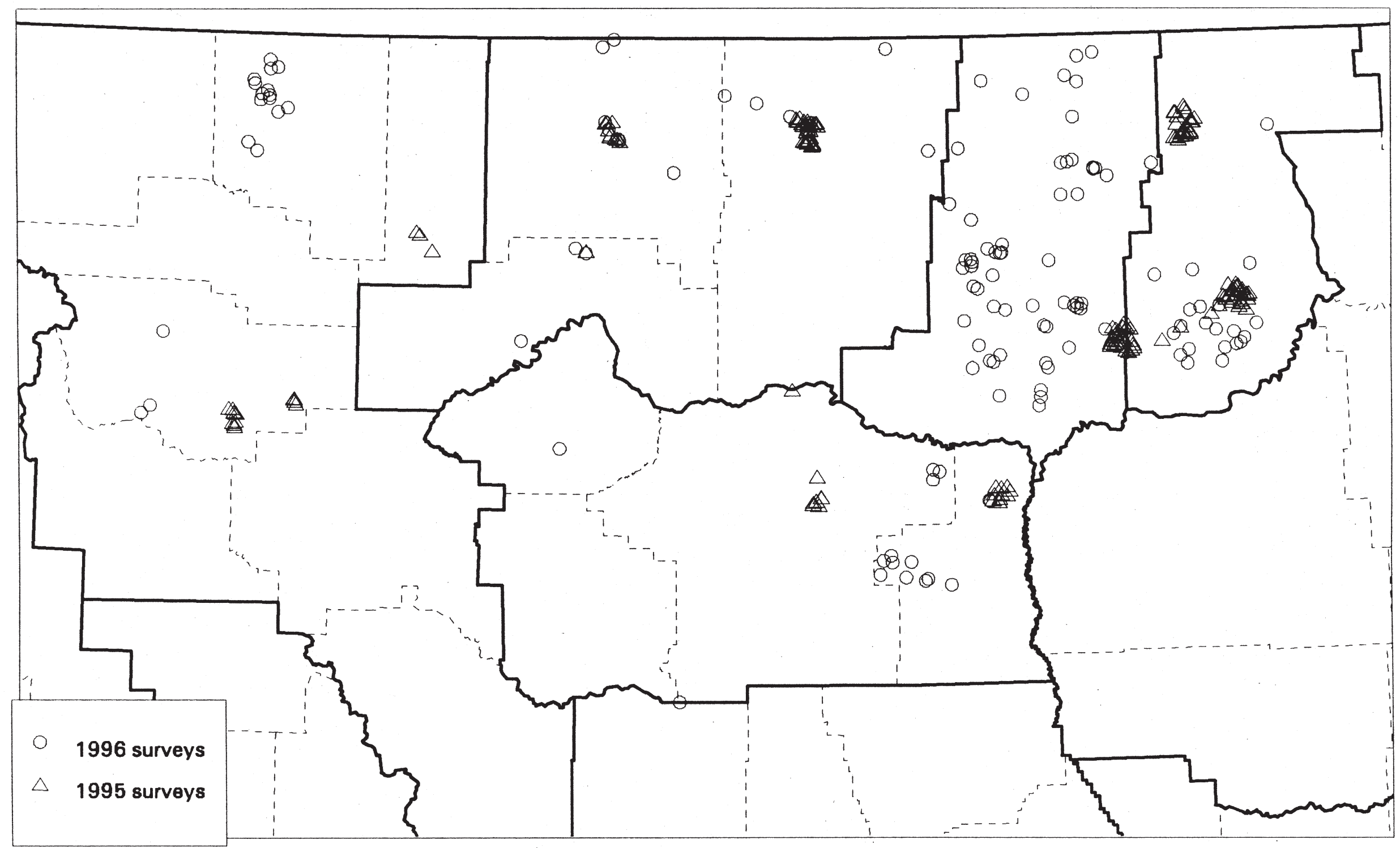

Montana Natural Heritage Program, May 07, 1997 
Table 1. Breeding status of 8 species of colonial nesting bird and three other species on the Lewistown District, BLM, June 3 - July 25, 1997.

\begin{tabular}{|c|c|c|c|c|c|c|c|}
\hline Year & Month & Day & Species & Location & $\begin{array}{c}\text { Township/ } \\
\text { Range }\end{array}$ & Section & $\begin{array}{c}\text { Breeding } \\
\text { Status }\end{array}$ \\
\hline 1996 & 6 & 17 & AMERICAN WHITE PELICAN & War Horse Reservoir & T16NR25E & 29 & Transient \\
\hline 1996 & 7 & 24 & AMERICAN WHITE PELICAN & Wild Horse Reservoir & T27NR27E & 2 & Transient \\
\hline 1996 & 7 & 25 & AMERICAN WHITE PELICAN & Reservoir no. 161 & T28NR28E & 22 & Transient \\
\hline 1996 & 6 & 5 & BLACK-CROWNED NIGHT-HERON & Pond ca. 2 mi. SE of Shaver Ranch & T28NR27E & 2 & Breeding \\
\hline 1996 & 6 & 1 & BLACK-TERN & Ca. $2.5 \mathrm{mi}$ East of Oilmont & T35NR02W & 31 & Transient \\
\hline 1996 & 7 & 11 & BLACK TERN & Unnamed reservoir on Fifteenmile Creek & T34NR21E & 18 & Probable \\
\hline 1996 & 7 & 24 & BLACK TERN & Wild Horse Reservoir & T27NR27E & 2 & Probable \\
\hline 1996 & 7 & 24 & BLACK TERN & Lower Wild Horse Reservoir & T27NR27E & 1 & Probable \\
\hline 1996 & 7 & 25 & BLACK TERN & Milk River WMA & T32NR33E & 30 & Probable \\
\hline 1996 & 6 & 4 & CALIFORNIA GULL & North Chinook Reservoir & T35NR18E & 24 & Breeding \\
\hline 1996 & 6 & 4 & CALIFORNIA GULL* & Ca. 20 mile NE of Havre & T35NR17E & 10 & Transient \\
\hline 1996 & 7 & 24 & COMMON TERN & Wild Horse Reservoir & T27NR27E & 2 & Probable \\
\hline 1996 & 7 & 24 & COMMON TERN & Lower Wild Horse Reservoir & T27NR27E & 1 & Probable \\
\hline 1996 & 6 & 18 & COMMON TERN & Lewis Reservoir & T16NR24E & 20 & Probable \\
\hline 1996 & 7 & 24 & COMMON TERN & Ward Reservoir & T34NR39E & 28 & Probable \\
\hline 1996 & 7 & 23 & COMMON TERN & Two Forks Reservoir & T24NR37E & 12 & Probable \\
\hline 1996 & 7 & 24 & COMMON TERN & VR-2 Reservoir & T28NR36E & 23 & Probable \\
\hline 1996 & 6 & 1 & COMMON TERN & Lake $1.5 \mathrm{mi}$ NNE of Sunburst & T36NR02W & 5 & Transient \\
\hline 1996 & 6 & 17 & DOUBLE CRESTED CORMORANT & War Horse Reservoir & T16NR25E & 29 & Transient \\
\hline 1996 & 6 & 18 & DOUBLE-CRESTED CORMORANT & Lewis Reservoir & T16NR24E & 20 & Breeding \\
\hline 1996 & 6 & 3 & FORSTER'S TERN & Halfway Lake WPA (also call Sands WPA) & T32NR15E & 14 & Breeding \\
\hline 1996 & 6 & 4 & FORSTER'S TERN & North Chinook Reservoir & T35NR18E & 24 & Probable \\
\hline 1996 & 6 & 4 & FORSTER'S TERN & Ca. 20 mile NE of Havre & T35NR17E & 10 & Transient \\
\hline 1996 & 6 & 5 & FORSTER'S TERN & Pond $\mathrm{N}$ of Tressler Coulee & T28NR27E & 9 & Breeding \\
\hline 1996 & 6 & 18 & FORSTER'S TERN & Little Bear Lake & T16NR26E & 31 & Breeding \\
\hline
\end{tabular}


Table 1 (cont.). Breeding status of 8 species of colonial nesting bird and three other species on the Lewistown District, BLM, June 3 - July 25, 1997.

\begin{tabular}{|c|c|c|c|c|c|c|c|}
\hline Year & Month & Day & Species & Location & $\begin{array}{c}\text { Township/ } \\
\text { Range }\end{array}$ & Section & $\begin{array}{c}\text { Breeding } \\
\text { Status }\end{array}$ \\
\hline 1996 & 7 & 11 & FORSTER'S TERN & Tule Lake & T34NR20E & 24 & Breeding \\
\hline 1996 & 7 & 11 & FORSTER'S TERN & Unnamned Reservoir on Fifteen Mile Creek & T34NR20E & 24 & Transient \\
\hline 1996 & 7 & 24 & FORSTER'S TERN & Nelson Reservoir & T27NR30E & 32 & Transient \\
\hline 1996 & 6 & 4 & FORSTER'S TERN & North Chinook Reservoir & T35NR18E & 24 & Probable \\
\hline 1996 & 6 & 1 & FRANKLIN'S GULL & Temporary pond $3 \mathrm{mi}$. E., $2.4 \mathrm{mi}$. N. of Kevin & T35NR02W & 20 & Transient \\
\hline 1996 & 6 & 19 & FRANKLIN'S GULL & Unnamed Reservoir $1.5 \mathrm{mi}$ WNW of Holland Reservoir & T20NR26E & 17 & Transient \\
\hline 1996 & 7 & 11 & FRANKLIN'S GULL & Unnamed reservoir on Fifteenmile Creek & T34NR21E & 18 & Transient \\
\hline 1996 & 6 & 4 & RING-BILLED GULL & North Chinook Reservoir & T35NR18E & 24 & Breeding \\
\hline 1996 & 6 & 2 & RING-BILLED GULL & Middle Chain-of-Lakes merged with West Chain-of-Lakes & T33NR13E & 5 & Breeding \\
\hline 1996 & 6 & 4 & RING-BILLED GULL & Ca. 20 mile NE of Havre & T35NR17E & 10 & Transient \\
\hline 1996 & 6 & 17 & RING-BILLED GULL & War Horse Reservoir & T16NR25E & 29 & Transient \\
\hline 1996 & 7 & 24 & RING-BILLED GULL & Pea Lake & T37NR31E & 35 & Probable \\
\hline 1996 & 6 & 1 & RING-BILLED GULL & Temporary pond $3 \mathrm{mi}$. E., $2.4 \mathrm{mi}$. N. of Kevin & T35NR02W & 20 & Transient \\
\hline 1996 & 7 & 22 & RING-BILLED GULL & Bynum Reservoir & T25NR06W & 6 & Transient \\
\hline 1996 & 7 & 25 & RING-BILLED GULL & Reservoir no. 161 & T28NR28E & 22 & Transient \\
\hline 1996 & 7 & 11 & BAIRD'S SPARROW & Unnamed Reservoir & T33NR26E & 13 & Probable \\
\hline 1996 & 7 & 22 & COMMON LOON & Pishkin Reservoir & T22NR07W & 3 & Transient \\
\hline 1996 & 7 & 25 & LOGGERHEAD SHRIKE & McChesney Reservoir & T32NR34E & 12 & Breeding \\
\hline 1996 & 7 & 22 & PEREGRINE FALCON & Pond off NW side Pishkin Reservoir & T22NR07W & 3 & Transient \\
\hline
\end{tabular}


Table 2. Numbers of pairs of colonial nesting birds seen on the Lewistown District during 1996.

\begin{tabular}{|c|c|c|c|c|c|c|c|c|}
\hline Location & DCCO & $\mathrm{BCNH}$ & CAGU & RBGU & COTE & FOTE & BLTE & Comments \\
\hline \multicolumn{9}{|l|}{ GREAT FALLS R.A. } \\
\hline Pishkin Res (pond off NE side) & & & & & & & 3 & saw Peregrine hunting \\
\hline \multicolumn{9}{|l|}{ HAVRE R.A. } \\
\hline N Chinook Res. & & & 100 & 100 & & 2 prob & & \\
\hline Halfway Lake & & & & & & 20 & & \\
\hline Middle Chain of Lakes & & & & 4 & & & & \\
\hline Tule Lake & & & & & & $6-10$ & & \\
\hline Fifteen Mile Res. & & & & & & & 2 prob & \\
\hline \multicolumn{9}{|l|}{ JUDITH R.A. } \\
\hline Little Bear Lake & & & & & & 3 & & \\
\hline Lewis Res. & 5 & & & & 1 prob & & & \\
\hline
\end{tabular}

DCCO = Double-crested Cormorant, BCNH = Black-crowned Night-Heron, CAGU = California Gull, RBGU = Ring-billed Gull, COTE = Common Tern, FOTE = Forster's Tern, BLTE $=$ Black Tern . 
Table 2 (cont.). Numbers of pairs of colonial nesting birds seen on the Lewistown District during 1996.

\begin{tabular}{|c|c|c|c|c|c|c|c|c|}
\hline Location & DCCO & $\mathrm{BCNH}$ & CAGU & RBGU & COTE & FOTE & BLTE & Comments \\
\hline \multicolumn{9}{|l|}{ PHILLIPS R.A. } \\
\hline Whitewater Lake & & & & 30 & & & & \\
\hline Pea Lake & & & & 3 prob & & & & \\
\hline Wild Horse Res. & & & & & 10 & & 1 prob & \\
\hline Lower Wild Horse Res. & & & & & 5 prob & & 2 prob & \\
\hline Milk River WMA & & & & & & & $\begin{array}{l}10 \\
\text { prob }\end{array}$ & \\
\hline Mud Lake & & & & & 2 & & & \\
\hline $\begin{array}{l}\text { pond T28N R27E S2 NE } \\
\text { ("Hoss Reservoir") }\end{array}$ & & $5-8$ & & & & & & \\
\hline pond T28N R27E S9 W & & & & & & 1 & & \\
\hline \multicolumn{9}{|l|}{ VALLEY R.A. } \\
\hline Ward Res. & & & & & 6 prob & & & \\
\hline Two Forks Res. & & & & & 1 prob & & & \\
\hline VR-2 Res. & & & & & 4 prob & & & \\
\hline
\end{tabular}

DCCO = Double-crested Cormorant, BCNH = Black-crowned Night-Heron, CAGU = California Gull, RBGU = Ring-billed Gull, COTE = Common Tern, FOTE = Forster's Tern, BLTE $=$ Black Tern . 
Table 3. Relationship of lake size to occupancy by TES colonial nesting waterbirds, Lewistown District, BLM ${ }^{1}$.

\begin{tabular}{|c|c|c|c|c|c|c|}
\hline Size (acres) & Survey sites & $\begin{array}{l}\text { Black-crowned } \\
\text { Night-Heron }\end{array}$ & $\begin{array}{l}\text { Black-necked } \\
\text { Stilt }\end{array}$ & $\begin{array}{l}\text { Common } \\
\text { Tern }\end{array}$ & Forster's Tern & Black Tern \\
\hline $0(\text { dry })^{2}$ & 44 & & & & & \\
\hline $.1-10$ & 116 & 1 & & & & \\
\hline $11-40$ & 38 & & & 2 & 1 & \\
\hline $41-100$ & 36 & & & 1 & & 1 \\
\hline $101-1000$ & 28 & & & 4 & 4 & 3 \\
\hline$>1000$ & 7 & 1 & 1 & 1 & 1 & 2 \\
\hline Total & 269 & 2 & 1 & 8 & 6 & 6 \\
\hline
\end{tabular}

Data were pooled from 1995 and 1996 field surveys.

${ }^{2}$ Lakes were selected for surveying by being $>40$ acres in the Montana 100k GIS coverage and on or adjacent to BLM lands; however they were dry at the time of survey. 
Table 4. Relationship of shoreline emergent vegetation to occupancy by colonial nesting waterbirds in wetlands > 5 acres, Lewistown District, BLM $^{1}$.

\begin{tabular}{|c|c|c|c|c|c|c|}
\hline $\begin{array}{l}\% \text { of shoreline } \\
\text { w/ emergent } \\
\text { veg }\end{array}$ & Survey sites & $\begin{array}{l}\text { Black-crowned } \\
\text { Night-Heron }\end{array}$ & $\begin{array}{l}\text { Black-necked } \\
\text { Stilt }^{2}\end{array}$ & $\begin{array}{l}\text { Common } \\
\text { Tern }\end{array}$ & Forster's Tern & Black Tern \\
\hline 0 & 9 & & 2 & 1 & & \\
\hline $1-25$ & 20 & 1 & & & 1 & 1 \\
\hline $26-50$ & 18 & & 1 & 1 & 1 & \\
\hline $51-100$ & 74 & 1 & 3 & 6 & 3 & 5 \\
\hline Total & 121 & 2 & 6 & 8 & 5 & 6 \\
\hline
\end{tabular}

Data were pooled from 1995 and 1996 field surveys.

Table 5. Relationship of lake permanence to occupancy by colonial nesting waterbirds in wetlands $>5$ acres, Lewistown District, BLM ${ }^{1}$.

\begin{tabular}{|c|c|c|c|c|c|c|}
\hline Permanence & Survey sites & $\begin{array}{l}\text { Black-crowned } \\
\text { Night-Heron }\end{array}$ & $\begin{array}{l}\text { Black-necked } \\
\text { Stilt }\end{array}$ & $\begin{array}{l}\text { Common } \\
\text { Tern }\end{array}$ & Forster's Tern & Black Tern \\
\hline Permanent & 65 & 1 & 1 & 7 & 4 & 6 \\
\hline Temporary & 62 & 1 & 0 & 1 & 2 & 0 \\
\hline Total & 127 & 2 & 1 & 8 & 6 & 6 \\
\hline
\end{tabular}

Data were pooled from 1995 and 1996 field surveys. 
been recorded, and 116 sites larger than 5 acres, for which the percent of shoreline with emergent vegetation had been recorded. Because of the large size of Freezeout Lake and numerous Blacknecked Stilt breeding locations $(n=6)$, percent of shoreline with emergent vegetation was recorded independently for six sites. Therefore, the number of sites examined for relationships between site occupancy and emergent vegetation was 122 .

Lake sizes were grouped into 6 size classes (Table 3). With the exception of one Black-crowned Night-Heron colony on a site of 7 acres, occupied sites surveyed in 1995 and 1996 were larger than 10 acres. The majority (83\%) of occupied sites were 40 acres or larger. The association of three species of colonial nesting shore- and water birds with larger wetlands/ wetland complexes was demonstrated in Iowa by Brown and Dinsmore (1986), where Black Tern, Forster's Tern and Black-crowned Night-Heron tended to be associated with marshes that were larger than 45 acres.

Data on percent of shoreline with emergent vegetation were grouped into four classes (Table 4). Seventy-eight percent of occupied sites had emergent vegetation along more than 25 percent of the shoreline. Three occupied sites (11\%) had no emergent vegetation, two for Black-necked Stilts and one for common tern. These two species frequently nest in open areas (Reichel 1996, Johnsgard 1979).

Eighty-three percent of the occupied sites were on permanent bodies of water (Table 5). It is likely that the temporary bodies of water that were occupied will hold water through the breeding season. None of the dry sites were occupied by colonial nesting birds. Similarly, in the prairie pothole region of North Dakota Kantrud and Stewart (1984) found semipermanent wetlands supported substantially more breeding shore- and waterbirds.

\section{Black-crowned Night-Heron}

In North America, inland colonies of Black-crowned Night-Heron tend to be located in large wetland complexes with substantial emergent vegetation (Brown and Dinsmore 1986, Davis 1993). Only two occupied sites were found during the 1995 and 1996 surveys, Freezeout Lake (4,000 acres) and "Hoss Reservoir" (7 acres). "Hoss Reservoir" is a temporary body of water with only sparse emergent vegetation. There are a number of temporary and permanent bodies of water in the vicinity of "Hoss Reservoir", which may contribute the maintenance of a colony at this site.

\section{Black-necked Stilt}

Only one survey site, Freezeout Lake, visited in 1995 contained nesting Black-necked Stilts. Black-necked Stilts nest in medium to large wetland complexes in Montana (Reichel 1996). Freezeout Lake is one of 5 reported breeding locations in Montana.

\section{Common Tern}

In the Great Plains most Common Tern nesting occurs on islands in large lakes or reservoirs in sparsely vegetated areas, but near vegetation (Johnsgard 1979). However, in Canada, Common 
Terns occasionally nest in marshes (Godfry 1986). On the Lewistown District 8 sites, all larger than 30 acres, were occupied by Common Terns and all, but one site, had emergent vegetation along more than $25 \%$ of the shoreline. One occupied site had no emergent vegetation and was a temporary body of water. All nesting occurred on islands.

\section{Forster's Tern}

Forster's tern is described as a bird that inhabits large marsh complexes (Brown and Dinsmore 1986) and tends to avoid small marshes (Johnsgard 1979). On the Lewistown District five survey sites were occupied by Forster's Tern. Five of the 6 sites were larger than 100 acres and had emergent vegetation along more than $25 \%$ of the shoreline. Two of the sites were on temporary bodies of water.

\section{Black Tern}

Black Terns typically nest in shallow freshwater marshes with emergent vegetation (Dunn \& Argo 1995). In prairie marshes in Iowa, Black Terns preferred marshes of 50+ acres (Brown and Dinsmore 1986) and in North Dakota, $72 \%$ of nests were in semipermanent ponds (Kantrud and Stewart 1984). During the 1995 and 1996 surveys on the Lewistown District, 6 survey sites were occupied by Black Terns. All occupied sites were larger than 40 acres and 5 of the 6 sites were larger than 100 acres. Five of the 6 sites had emergent vegetation along more than $50 \%$ of the shoreline.

\section{RECOMMENDATIONS}

Recommendations for further work on colonial nesting shore- and waterbirds and management were provided by Reichel (1996). These recommendations are presented below with only minor modification.

\section{Surveys, Monitoring and Research}

1) All incidental sightings and specific surveys of breeding or possibly breeding colonial nesting wetland birds should be recorded and maintained for future area biologist's use. Ideally, copies should be forwarded to the Natural Heritage Program, which maintains a state-wide database (BCD) on these species. These can be used for land use planning and can also provide a backup in case of loss of originals or personnel turnover. Further, the BCD provides a statewide database of locations, productivity, and general landscape associations. At a minimum, date, species, approximate numbers, precise location, and evidence of breeding should be recorded.

2) Additional surveys should be conducted, concentrating on larger wetlands and wetland complexes on the district that currently have not been surveyed. Some previously visited large sites may not have been thoroughly surveyed and should be revisited. Also, temporary sites that were dry during 1996 surveys may hold water in other years and may be suitable for nesting birds when water is present. 
3) Following additional surveys, a monitoring program should be initiated, with resurveying of known current and historic sites at least every 5 years. Resurveying should be done by visiting a colony twice in a single year: once in late spring to determine if breeding took place, and once in mid-summer to check if reproduction was successful. Ideal dates are species- and locationspecific, and may vary with annual weather conditions and water level.

4) Life history and ecology of the wetland colonial nesting birds in Montana is poorly known for most species. Long-term monitoring will provide information on timing of and habitat requirements needed for successful breeding.

5) It is recommended that any wetland areas over 20 acres, which are under consideration for mining, road building, grazing lease renewal, or other large-scale potentially habitat altering activities, be surveyed thoroughly for colonial nesting bird presence and breeding activity.

\section{Management}

With an increasing number of colonial nesting wetland bird species on the decline, it seems reasonable to pro-actively manage habitat to support them. While not all ways of preserving these species are currently known, several management activities could certainly negatively impact them. Without adequate breeding areas, these species cannot survive, and the type of wetland area used is often species-specific.

a. All colonial nesting wetland birds are sensitive to disturbance during much or all of the breeding season; therefore, disturbance should be minimized during the breeding season. This is often best done by limiting access, and certainly not by improving access or by encouraging use of the area for unrelated activities.

b. Cattle trampling may severely impact shore nesting species such as Black-necked Stilts or Piping Plovers. If possible, grazing use should be timed to follow the nesting season.

c. Dramatic changes in water level may significantly impact reproduction. For most species a large rise in water level following nesting will destroy many nests. Conversely, a large drop in level may result in connecting nesting islands to the mainland or draining breeding marshes of such species as Franklin's Gulls and exposing the colonies to vastly increased predation. 


\section{LITERATURE CITED}

Brown, M. and J.J. Dinsmore. 1986. Implications of marsh size and isolation for marsh bird management. J. Wildl. Manage. 50:392-397.

Davis, W. E., Jr. 1993. Black-crowned Night-Heron (NYCTICORAX NYCTICORAX). In: The Birds of North America, No. 74 (A. Poole and F. Gill, Eds.). Philadelphia: The Academy of Natural Sciences; Washington D.C.: The American Ornithologists Union. 20 pp.

Dunn, E. H., and D. J. Agro. 1995. Black Tern (CHLIDONIAS NIGER). In: The Birds of North America, No. 147 (A. Poole and F. Gill, Eds.). Philadelphia: The Academy of Natural Sciences; Washington D.C.: The American Ornithologists Union. 24 pp.

Godfrey, W. E. 1986. The birds of Canada. Revised edition. Distributed for National Museum of Natural Sciences, Ottawa, by Univ. Chicago Press. 596 pp.

Johnsgard, P. A. 1979. Birds of the Great Plains: breeding species and their distribution. Univ. Nebraska Press, Lincoln. 539 pp.

Kantrud, H.A. and R.E. Stewart. 1984. Ecological distribution and crude density of breeding birds on prairie wetlands. J. Wildl. Manage. 48:426-437.

Reichel, J. D. 1996. Preliminary Colonial Nesting Bird Survey of the Bureau of Land Management Lewistown District: 1995. Montana Natural Heritage Program. Helena, MT. 97 pp. 


\section{A P P E N D I X 1}

Characteristics of wetland sites surveyed for colonial nesting birds,

Bureau of Land Management, Lewistown District, June - July, 1996. 
Appendix 1. Characteristics of sites surveyed for colonial nesting birds, Bureau of Land Management, Lewistown District, June - July, 1996.

\begin{tabular}{|c|c|c|c|c|c|c|c|c|c|c|c|c|c|c|c|}
\hline County & MO & DA & YEAR & LOCATION & T \& R & SEC & \begin{tabular}{|l|} 
APPROX. \\
ACRES \\
\end{tabular} & ORIGIN & DESCRIPTION & DEPTH & $\mathrm{pH}$ & $\begin{array}{l}\% \text { SHORELINE } \mathbf{w} / \\
\text { EMERGENT VEG. } \\
\end{array}$ & $\begin{array}{l}\text { EMERGENT VEG. } \\
\text { SPECIES } \\
\end{array}$ & \begin{tabular}{|l|} 
SURVEY \\
SUCCESS \\
\end{tabular} & HERPS \\
\hline Blaine & 6 & 3 & 1996 & East Martin Lake & 035N017E & 34 & 4 & & temporary lake/pond & & & & & $\mathrm{N}$ & \\
\hline Blaine & 6 & 4 & 1996 & $\begin{array}{l}\text { Ca. } 20 \text { mile NE of } \\
\text { Havre }\end{array}$ & 035N017E & 10 & 54 & $m$ & permanent lake/pond & $\operatorname{deep}(>2 m)$ & 5.5 & $>51 \%$ & sedge & $\mathrm{N}$ & PSTR \\
\hline Blaine & 7 & 10 & 1996 & Akali Lake & 037N023E & 13 & 275 & $n$ & permanent lake/pond & medium (1-2m) & 8 & $26-50 \%$ & sedge & $\mathrm{N}$ & \\
\hline Blaine & 7 & 11 & 1996 & $\begin{array}{l}\text { Unnamed Reservoir on } \\
\text { Fifteenmile Creek }\end{array}$ & 034N021E & 18 & 68 & $m$ & temporary lake/pond & medium (1-2m) & & $>51 \%$ & rush, sedge & $\mathrm{Y}$ & \\
\hline Blaine & 7 & 11 & 1996 & $\begin{array}{l}\text { Unnamed Pothole, } 3 \mathrm{mi} \\
\text { E and } 9.5 \mathrm{mi} \mathrm{N} \text { of } \\
\text { Chinook }\end{array}$ & 034N020E & 5 & 15 & $n$ & temporary lake/pond & medium (1-2m) & 5.5 & $>51 \%$ & sedge, rush & $\mathrm{Y}$ & \\
\hline Blaine & 7 & 11 & 1996 & $\begin{array}{l}\text { Pothole, ca. } 12 \text { miles } \\
\text { northeast of Savoy }\end{array}$ & 033N025E & 23 & 50 & $n$ & temporary lake/pond & $\begin{array}{l}\begin{array}{l}\text { shallow/small } \\
(<1 \mathrm{~m})\end{array} \\
\end{array}$ & & $>51 \%$ & rush, sedge & $\mathrm{N}$ & \\
\hline Chouteau & 6 & 1 & 1996 & $\begin{array}{l}\text { Lake just E of } \\
\text { Lonesome Lake }\end{array}$ & 029N011E & 14 & 47 & $m$ & temporary lake/pond & & & $>51 \%$ & polygonum, rush, sedge & $\mathrm{N}$ & \\
\hline Chouteau & 6 & 2 & 1996 & Lonesome Lake & 029N012E & 19 & 731 & $n$ & temporary lake/pond & & 5.5 & $>51 \%$ & polygonum, rush, sedge & $\mathrm{N}$ & PSTR \\
\hline Chouteau & 6 & 3 & 1996 & $\begin{array}{l}\text { Kingsbury Lake, } \\
\text { Kingsbury WPA }\end{array}$ & 021N011E & 17 & 1376 & $n$ & permanent lake/pond & $\operatorname{deep}(>2 m)$ & 7.5 & $1-25 \%$ & juncus, polygonum & $\mathrm{N}$ & PSTR \\
\hline Fergus & 6 & 17 & 1996 & $\begin{array}{l}1.2 \text { mi. NNE of Judith } \\
\text { Gap }\end{array}$ & $011 \mathrm{~N} 016 \mathrm{E}$ & 20 & 13 & $m$ & permanent lake/pond & $\operatorname{deep}(>2 m)$ & 6.5 & $>51 \%$ & rush, cattail, sedge & $\mathrm{N}$ & $\begin{array}{l}\text { PSTR, } \\
\text { RAPI }\end{array}$ \\
\hline Fergus & 6 & 19 & 1996 & $\begin{array}{l}\text { Unnamed Reservoir } 1.5 \\
\text { mi WNW of Holland } \\
\text { Reservoir }\end{array}$ & 020N026E & 17 & 36 & $m$ & permanent lake/pond & & & $1-25 \%$ & rush, foxtail & $\mathrm{N}$ & \\
\hline Fergus & 6 & 19 & 1996 & Holland Reservoir & 020N026E & 15 & 23 & $m$ & permanent lake/pond & & & $1-25 \%$ & rush, foxtail & $N$ & \\
\hline Fergus & 6 & 19 & 1996 & $\begin{array}{l}\text { Buffalo Wallow } \\
\text { Reservoir } \\
\end{array}$ & 020N026E & 29 & 24 & $m$ & permanent lake/pond & $\operatorname{deep}(>2 m)$ & 5.5 & $26-50 \%$ & rush, sedge & $\mathrm{N}$ & SCBO \\
\hline Hill & 6 & 2 & 1996 & $\begin{array}{l}\text { Middle Chain-of-Lakes } \\
\text { merged with West } \\
\text { Chain of Lakes }\end{array}$ & 033N013E & 5 & 105 & $n$ & temporary lake/pond & $\operatorname{deep}(>2 m)$ & 6.5 & $26-50 \%$ & sedge & $\mathrm{Y}$ & PSTR \\
\hline Hill & 6 & 2 & 1996 & $\begin{array}{l}\text { Lake at north end of } \\
\text { Chain-of-Lakes Coulee }\end{array}$ & 034N012E & 14 & 43 & $n$ & temporary lake/pond & medium (1-2m) & 7 & $>51 \%$ & sedge & $\mathrm{N}$ & PSTR \\
\hline$\overline{\text { Hill }}$ & 6 & 2 & 1996 & Ca. 7.5 miles $\mathrm{N}$ of & 034N012E & 24 & 27 & $n$ & temporary lake/pond & shallow/small & 6.5 & $>51 \%$ & sedge & $\mathrm{N}$ & PSTR \\
\hline
\end{tabular}

$\mathrm{n}=$ natural, $\mathrm{m}=$ man-made

AMTI $=$ Tiger Salamander (Ambystoma tigrinum), CHPI $=$ Painted Turtle $($ Chrysemys picta $)$, PSTR $=$ Western Chorus Frog $($ Pseudacris triseriata $)$, RAPI $=$ Northern Leopard Frog $($ Rana pipiens $)$,

SCBO = Plains Spadefoot (Scaphiopus bombifrons), THEL = Western Terrestrial Garter Snake (Thamnophis elegans) and THRA = Plains Garter Snake (Thamnophis radix) 
Appendix 1 (cont.). Characteristics of sites surveyed for colonial nesting birds, Bureau of Land Management, Lewistown District, June - July, 1996.

\begin{tabular}{|c|c|c|c|c|c|c|c|c|c|c|c|c|c|c|c|}
\hline County & Mo & DA & YEAR & LOCATION & $\mathbf{T} \& \mathbf{R}$ & SEC & \begin{tabular}{|c|} 
APPROX. \\
ACRES \\
\end{tabular} & ORIGIN & DESCRIPTION & DEPTH & $\mathrm{pH}$ & \begin{tabular}{|l|}
$\%$ SHORELINE w/ \\
EMERGENT VEG.
\end{tabular} & $\begin{array}{l}\text { EMERGENT VEG. } \\
\text { SPECIES }\end{array}$ & \begin{tabular}{l|} 
SURVEY \\
SUCCESS
\end{tabular} & HERPS ${ }^{+}$ \\
\hline
\end{tabular}

\begin{tabular}{|c|c|c|c|c|c|c|c|c|c|c|c|c|c|c|c|}
\hline & & & & Kremlin & & & & & & $(<1 \mathrm{~m})$ & & & & & \\
\hline$\overline{\text { Hill }}$ & 6 & 2 & 1996 & $\begin{array}{l}\text { Eastern-most Chain-of- } \\
\text { Lakes }\end{array}$ & 033N013E & 4 & 59 & $n$ & temporary lake/pond & medium (1-2m) & 6.5 & $26-50 \%$ & sedge & $\mathrm{N}$ & PSTR \\
\hline$\overline{\text { Hill }}$ & 6 & 3 & 1996 & $\begin{array}{l}\text { Halfway Lake W. P. A. } \\
\text { also called Sands } \\
\text { WPA.) }\end{array}$ & 032N015E & 14 & 241 & $m$ & permanent lake/pond & $\operatorname{deep}(>2 m)$ & 7.5 & $1-25 \%$ & & $\mathrm{Y}$ & PSTR \\
\hline Hill & 6 & 3 & 1996 & $\begin{array}{l}\text { Lake on North side of } \\
\text { Wild Horse Lake }\end{array}$ & 037N013E & 6 & 37 & $n$ & temporary lake/pond & $\begin{array}{l}\text { shallow/small } \\
(<1 \mathrm{~m})\end{array}$ & 6 & $1-25 \%$ & & $\mathrm{~N}$ & PSTR \\
\hline Hill & 6 & 3 & 1996 & $\begin{array}{l}\text { West end of Wild } \\
\text { Horse Lake Bed }\end{array}$ & 037N012E & 15 & 24 & $n$ & temporary lake/pond & $\begin{array}{l}\text { shallow/small } \\
(<1 \mathrm{~m})\end{array}$ & 5.5 & $>51 \%$ & & $\mathrm{~N}$ & PSTR \\
\hline Petroleum & 6 & 17 & 1996 & War Horse Reservoir & 016N025E & 29 & 1444 & $m$ & permanent lake/pond & $\operatorname{deep}(>2 m)$ & 6.5 & $>51 \%$ & rush, sedge, foxtail & $\mathrm{Y}$ & $\begin{array}{l}\text { PSTR, } \\
\text { SCBO }\end{array}$ \\
\hline Petroleum & 6 & 18 & 1996 & Wild Horse Lake & 016N025E & 3 & 1595 & $n$ & temporary lake/pond & medium (1-2m) & & $>51 \%$ & foxtail, unkn. Forb & $\mathrm{N}$ & \\
\hline Petroleum & 6 & 18 & 1996 & Lewis Reservoir & 016N024E & 20 & 137 & $m$ & permanent lake/pond & $\operatorname{deep}(>2 m)$ & 6 & $>51 \%$ & rush, sedge & $\mathrm{Y}$ & $\begin{array}{l}\text { PSTR, } \\
\text { RAPI }\end{array}$ \\
\hline Petroleum & 6 & 18 & 1996 & $\begin{array}{l}\text { Temporary lake } 0.6 \mathrm{mi} \\
\text { NE of Blakeslee School }\end{array}$ & 017N024E & 27 & 121 & $n$ & temporary lake/pond & medium (1-2m) & & & rush, sedge & $\mathrm{N}$ & \\
\hline Petroleum & 6 & 18 & 1996 & $\begin{array}{l}\text { Upper Duck Creek } \\
\text { Reservoir }\end{array}$ & 016N024E & 4 & 23 & $m$ & temporary lake/pond & medium (1-2m) & & $>51 \%$ & rush, sedge & $\mathrm{N}$ & \\
\hline Petroleum & 6 & 18 & 1996 & Duck Creek Reservoir & 016N024E & 2 & 53 & $m$ & permanent lake/pond & $\operatorname{deep}(>2 m)$ & & $26-50 \%$ & rush, sedge, grass & $\mathrm{N}$ & \\
\hline Petroleum & 6 & 18 & 1996 & Vogel Reservoir & 015N027E & 6 & 61 & $m$ & permanent lake/pond & $\operatorname{deep}(>2 \mathrm{~m})$ & & & rush, bulrush & $\mathrm{N}$ & \\
\hline Petroleum & 6 & 18 & 1996 & Little Bear Lake & 016N026E & 31 & 138 & $n$ & temporary lake/pond & $\begin{array}{l}\text { shallow/small } \\
(<1 \mathrm{~m})\end{array}$ & 6 & & foxtail & $\mathrm{Y}$ & $\begin{array}{l}\text { PSTR, } \\
\text { RAPI }\end{array}$ \\
\hline Petroleum & 6 & 19 & 1996 & Drag Reservoir & 019N028E & 21 & 91 & $m$ & permanent lake/pond & & & $26-50 \%$ & rush, bulrush, sedge & $\mathrm{N}$ & \\
\hline Petroleum & 6 & 19 & 1996 & $\begin{array}{l}\text { Pond just below Drag } \\
\text { Reservoir }\end{array}$ & 019N028E & 27 & 3 & $\mathrm{~m}$ & temporary lake/pond & medium (1-2m) & 6 & $>51 \%$ & cattail, bulrush, rush & $\mathrm{N}$ & $\begin{array}{l}\text { CHPI, } \\
\text { THRA } \\
\end{array}$ \\
\hline Phillips & 6 & 4 & 1996 & Martin Lake & 034N017E & 4 & 356 & $n$ & temporary lake/pond & $\begin{array}{l}\text { shallow/small } \\
(<1 \mathrm{~m})\end{array}$ & 5.5 & $>51 \%$ & sedge & $\mathrm{N}$ & PSTR \\
\hline Phillips & 6 & 4 & 1996 & $\begin{array}{l}\text { Lake S of Shawn } \\
\text { Ranch }\end{array}$ & 029N027E & 33 & 207 & $n$ & temporary lake/pond & $\begin{array}{l}\text { shallow/small } \\
(<1 \mathrm{~m})\end{array}$ & 5.5 & $>51 \%$ & salt grass, small forb & $\mathrm{N}$ & PSTR \\
\hline Phillips & 6 & 4 & 1996 & Dodson Reservoir & 031N026E & 26 & 39 & $m$ & permanent lake/pond & & 6 & $>51 \%$ & cattail, sedge, rush & $\mathrm{N}$ & $\begin{array}{l}\text { PSTR, } \\
\text { RAPI }\end{array}$ \\
\hline Phillips & 6 & 4 & 1996 & \begin{tabular}{|l|} 
Pont of Rocks \\
Reservoir \\
\end{tabular} & 030N027E & 15 & 129 & & permanent lake/pond & & & $26-50 \%$ & cattail, bulrush & $\mathrm{N}$ & \\
\hline
\end{tabular}

$\mathrm{n}=$ natural, $\mathrm{m}=$ man-made

AMTI = Tiger Salamander (Ambystoma tigrinum), CHPI = Painted Turtle $($ Chrysemys picta $)$, PSTR $=$ Western Chorus Frog $($ Pseudacris triseriata $), \mathrm{RAPI}=$ Northern Leopard Frog $($ Rana pipiens $)$,

$\mathrm{SCBO}=$ Plains Spadefoot (Scaphiopus bombifrons), THEL = Western Terrestrial Garter Snake (Thamnophis elegans) and THRA = Plains Garter Snake $($ Thamnophis radix) 
Appendix 1 (cont.). Characteristics of sites surveyed for colonial nesting birds, Bureau of Land Management, Lewistown District, June - July, 1996.

\begin{tabular}{|c|c|c|c|c|c|c|c|c|c|c|c|c|c|c|c|}
\hline County & MO & DA & YEAR & LOCATION & $T \& R$ & SEC & \begin{tabular}{|c|} 
APPROX. \\
ACRES \\
\end{tabular} & ORIGIN & DESCRIPTION & DEPTH & $\mathrm{pH}$ & \begin{tabular}{|l|}
$\%$ SHORELINE w/ \\
EMERGENT VEG.
\end{tabular} & $\begin{array}{c}\text { EMERGENT VEG. } \\
\text { SPECIES } \\
\end{array}$ & \begin{tabular}{|c|} 
SURVEY \\
SUCCESS \\
\end{tabular} & HERPS ${ }^{+}$ \\
\hline
\end{tabular}

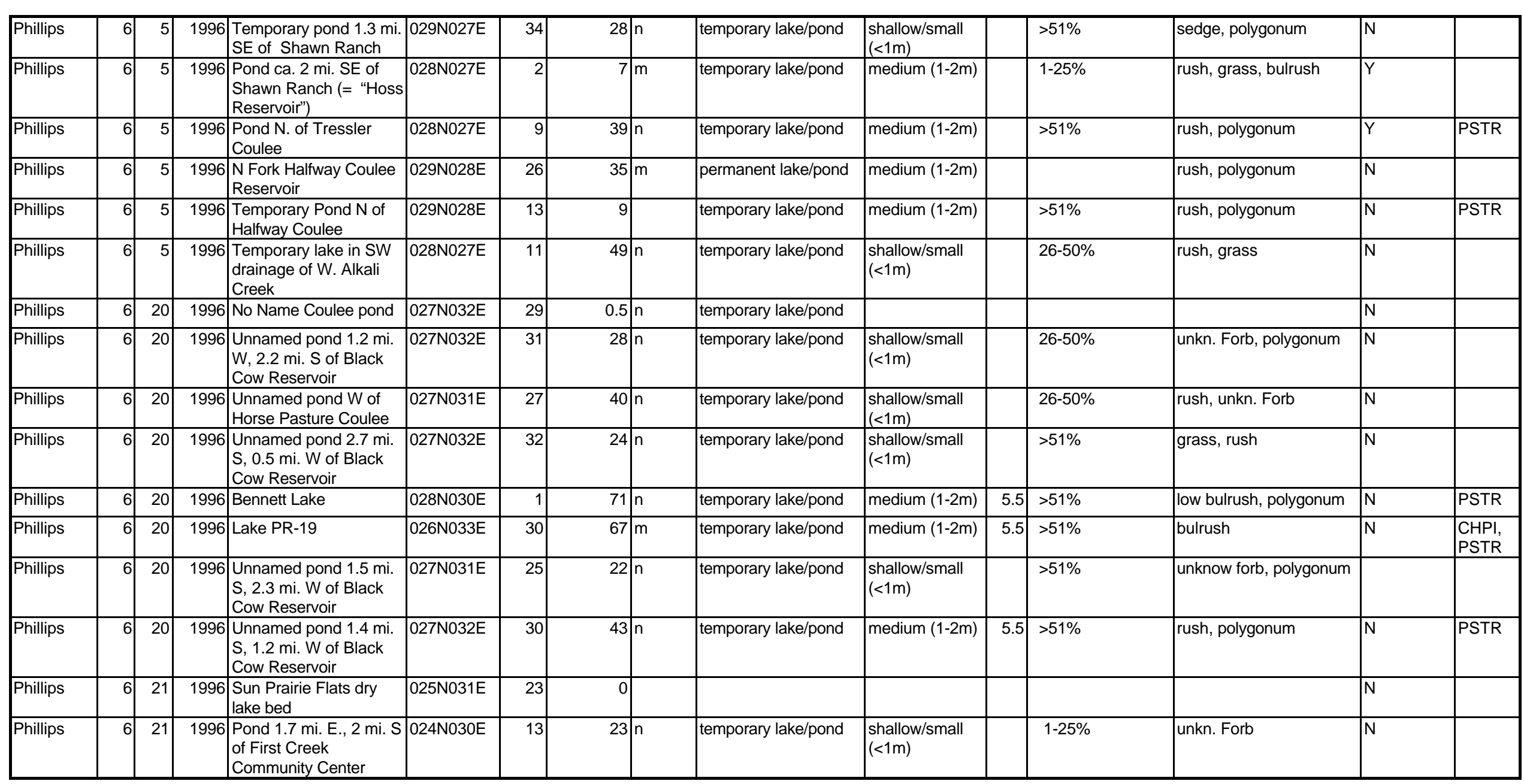

$\mathrm{n}=$ natural, $\mathrm{m}=$ man-made

AMTI $=$ Tiger Salamander (Ambystoma tigrinum), CHPI $=$ Painted Turtle $($ Chrysemys picta $)$, PSTR $=$ Western Chorus Frog $($ Pseudacris triseriata $)$, RAPI $=$ Northern Leopard Frog $($ Rana pipiens $)$,

$\mathrm{SCBO}=$ Plains Spadefoot (Scaphiopus bombifrons), THEL $=$ Western Terrestrial Garter Snake (Thamnophis elegans) and THRA $=$ Plains Garter Snake $($ Thamnophis radix) 
Appendix 1 (cont.). Characteristics of sites surveyed for colonial nesting birds, Bureau of Land Management, Lewistown District, June - July, 1996.

\begin{tabular}{|c|c|c|c|c|c|c|c|c|c|c|c|c|c|c|c|}
\hline County & Mo & DA & YEAR & LOCATION & $\mathbf{T} \& \mathbf{R}$ & SEC & \begin{tabular}{|c|} 
APPROX. \\
ACRES \\
\end{tabular} & ORIGIN & DESCRIPTION & DEPTH & $\mathrm{pH}$ & \begin{tabular}{|l|}
$\%$ SHORELINE w/ \\
EMERGENT VEG.
\end{tabular} & $\begin{array}{l}\text { EMERGENT VEG. } \\
\text { SPECIES }\end{array}$ & \begin{tabular}{l|} 
SURVEY \\
SUCCESS
\end{tabular} & HERPS ${ }^{+}$ \\
\hline
\end{tabular}

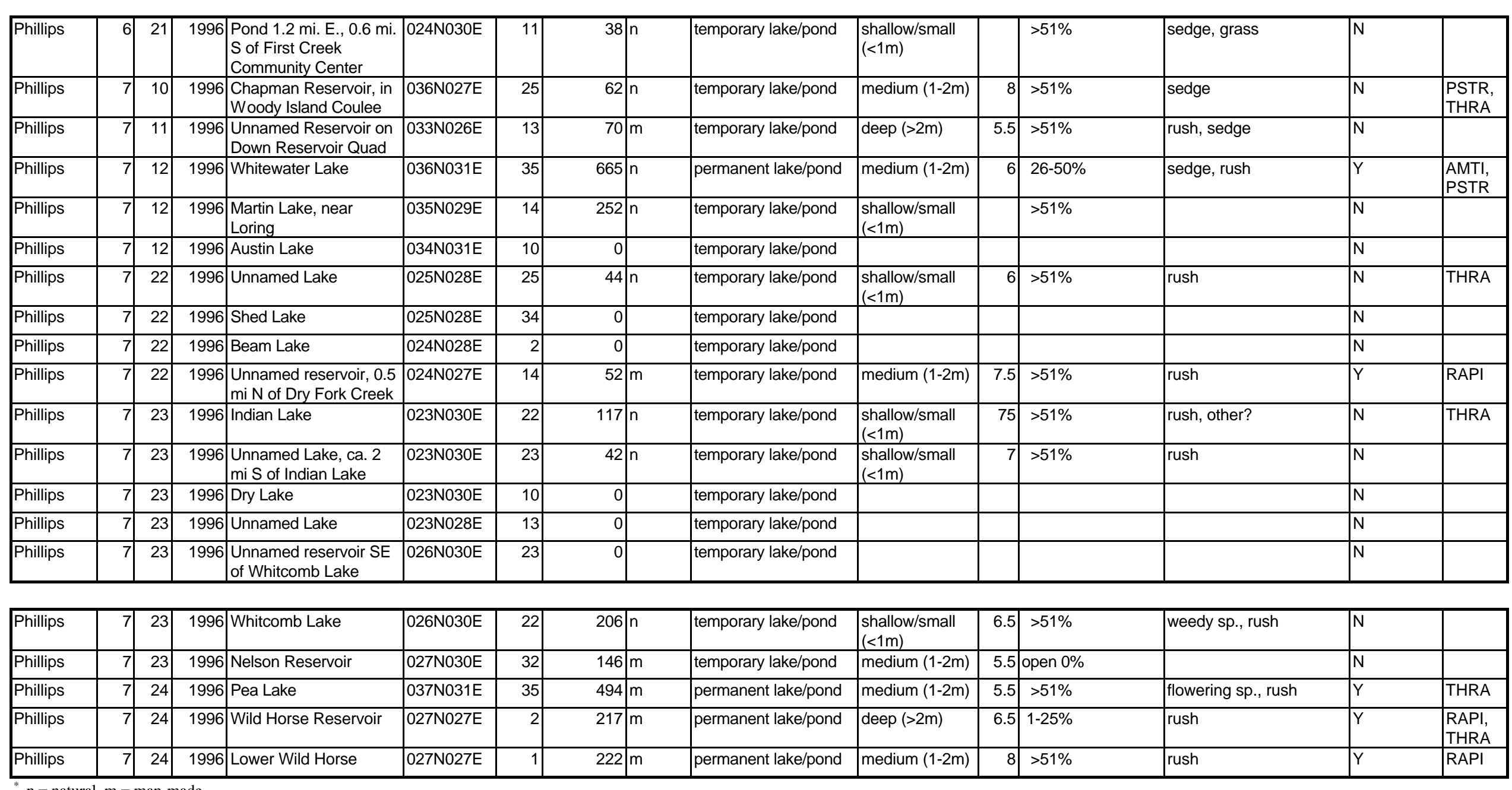

$\mathrm{n}=$ natural, $\mathrm{m}=$ man-made

AMTI $=$ Tiger Salamander $($ Ambystoma tigrinum $)$, CHPI $=$ Painted Turtle $($ Chrysemys picta $)$, PSTR $=$ Western Chorus Frog $($ Pseudacris triseriata $)$, RAPI $=$ Northern Leopard Frog $($ Rana pipiens $)$,

$\mathrm{SCBO}=$ Plains Spadefoot (Scaphiopus bombifrons), THEL = Western Terrestrial Garter Snake (Thamnophis elegans) and THRA = Plains Garter Snake $($ Thamnophis radix) 
Appendix 1 (cont.). Characteristics of sites surveyed for colonial nesting birds, Bureau of Land Management, Lewistown District, June - July, 1996.

\begin{tabular}{|c|c|c|c|c|c|c|c|c|c|c|c|c|c|c|c|}
\hline County & Mo & DA & YEAR & LOCATION & $T \& R$ & SEC & $\begin{array}{c}\text { APPROX. } \\
\text { ACRES }\end{array}$ & ORIGIN & DESCRIPTION & DEPTH & pH & $\begin{array}{l}\% \text { SHORELINE w/ } \\
\text { EMERGENT VEG. }\end{array}$ & $\begin{array}{l}\text { EMERGENT VEG. } \\
\text { SPECIES }\end{array}$ & \begin{tabular}{|l|} 
SURVEY \\
SUCCESS \\
\end{tabular} & HERPS ${ }^{+}$ \\
\hline
\end{tabular}

\begin{tabular}{|c|c|c|c|c|c|c|c|c|c|c|c|c|c|c|c|}
\hline & & & & Reservoir & & & & & & & & & & & \\
\hline Phillips & 7 & 24 & 1996 & \begin{tabular}{|l|} 
Unnamed Lake; off Hwy \\
191, ca. 1 mile N fo \\
Little Warm Creek \\
\end{tabular} & 026N027E & 10 & 0 & $n$ & temporary lake/pond & & & & & $\mathrm{N}$ & \\
\hline Phillips & 7 & 24 & 1996 & $\begin{array}{l}\text { Unnamed Lake, } 2 \text { mi } \\
\text { NW of Whitewater } \\
\text { Reservoir }\end{array}$ & 036N031E & 20 & 46 & $n$ & temporary lake/pond & $\begin{array}{l}\text { shallow/small } \\
(<1 \mathrm{~m})\end{array}$ & 5.5 & $>51 \%$ & rush, flowering sp. & $\mathrm{N}$ & \\
\hline Phillips & 7 & 24 & 1996 & \begin{tabular}{|l|} 
Unnamed reservoir, ca. \\
3 miles NE of Pea Lake \\
\end{tabular} & 037N032E & 29 & 71 & $m$ & permanent lake/pond & medium (1-2m) & 5.5 & $>51 \%$ & rush & $\mathrm{N}$ & \\
\hline Phillips & 7 & 25 & 1996 & Unnamed lake & 029N028E & 20 & 102 & $n$ & temporary lake/pond & $\begin{array}{l}\text { shallow/small } \\
(<1 \mathrm{~m})\end{array}$ & & $>51 \%$ & & $\mathrm{~N}$ & \\
\hline Phillips & 7 & 25 & 1996 & reservoir & 029N028E & 22 & 36 & $m$ & permanent lake/pond & medium (1-2m) & 6.5 & $>51 \%$ & rush & $\mathrm{N}$ & $\begin{array}{l}\text { RAPI, } \\
\text { THRA }\end{array}$ \\
\hline Phillips & 7 & 25 & 1996 & Reservoir no. 161 & 028N028E & 22 & 84 & $m$ & permanent lake/pond & medium (1-2m) & 7 & $1-25 \%$ & rush & $\mathrm{N}$ & $\mathrm{CHPI}$ \\
\hline Phillips & 7 & 25 & 1996 & Unnamed reservoir & 029N028E & 23 & 35 & $m$ & temporary lake/pond & medium $(1-2 m)$ & 7 & $1-25 \%$ & rush & $\mathrm{N}$ & \\
\hline Phillips & 7 & 25 & 1996 & Unnamed lake & 027N028E & 27 & 49 & $n$ & temporary lake/pond & $\begin{array}{l}\text { shallow/small } \\
(<1 \mathrm{~m})\end{array}$ & & $1-25 \%$ & & $\mathrm{~N}$ & \\
\hline Phillips & 7 & 25 & 1996 & Unnamed reservoir & 027N029E & 31 & 48 & $n$ & temporary lake/pond & $\begin{array}{l}\text { shallow/small } \\
(<1 \mathrm{~m})\end{array}$ & & $>51 \%$ & & $\mathrm{~N}$ & \\
\hline Phillips & 7 & 25 & 1996 & Milk River WMA & 032N033E & 30 & 340 & $m$ & permanent lake/pond & & & $>51 \%$ & bulrush, cattail, sedge & $\mathrm{N}$ & \\
\hline Phillips & 7 & 25 & 1996 & Mud Lake & 031N031E & 13 & 53 & $m$ & permanent lake/pond & & & open $0 \%$ & & $\mathrm{Y}$ & \\
\hline Phillips & 7 & 25 & 1996 & McNeil Slough & 032N032E & 15 & 26 & $n$ & permanent lake/pond & & & $>51 \%$ & cattail, willow & $\mathrm{N}$ & \\
\hline Phillips & 7 & 25 & 1996 & $\begin{array}{l}\text { Pond } 2.5 \mathrm{mi} \text { NNW of } \\
\text { Hewitt Lake }\end{array}$ & 032N031E & 2 & 10 & $\mathrm{~m}$ & temporary lake/pond & $\begin{array}{l}\text { shallow/small } \\
(<1 \mathrm{~m})\end{array}$ & & $26-50 \%$ & polygonum & $N$ & \\
\hline Phillips & 7 & 25 & 1996 & $\begin{array}{l}\text { Pond } 5 \text { miles west } \\
\text { northwest of Hewitt } \\
\text { Lake }\end{array}$ & 032N031E & 5 & 0 & $n$ & temporary lake/pond & & & & & $\mathrm{N}$ & \\
\hline Phillips & 7 & 25 & 1996 & $\begin{array}{l}\text { Pond } 2 \text { mi NE of } \\
\text { Bowdoin Lake } \\
\end{array}$ & 031N031E & 17 & 8 & $n$ & temporary lake/pond & & & $>51 \%$ & rush, sedge, grass & $\mathrm{N}$ & \\
\hline Phillips & 7 & 25 & 1996 & McChesney Reservoir & 032N034E & 12 & 81 & $m$ & permanent lake/pond & & & $>51 \%$ & willow, bulrush, rush & $\mathrm{N}$ & \\
\hline Phillips & 7 & 25 & 1996 & $\begin{array}{l}\text { Pond } 2.5 \text { mi northwest } \\
\text { of Hewitt Lake }\end{array}$ & 032N031E & 3 & 0 & $n$ & temporary lake/pond & & & & & $\mathrm{N}$ & \\
\hline Phillips & 7 & 25 & 1996 & Big McNeil Slough & 032N032E & 14 & 42 & $n$ & permanent lake/pond & & & $>51 \%$ & cattail, willow & $\mathrm{N}$ & \\
\hline
\end{tabular}

$\mathrm{n}=$ natural, $\mathrm{m}=$ man-made

AMTI $=$ Tiger Salamander (Ambystoma tigrinum), CHPI $=$ Painted Turtle $($ Chrysemys picta $)$, PSTR $=$ Western Chorus Frog $($ Pseudacris triseriata $), \mathrm{RAPI}=$ Northern Leopard Frog $($ Rana pipiens),

$\mathrm{SCBO}=$ Plains Spadefoot (Scaphiopus bombifrons), THEL = Western Terrestrial Garter Snake (Thamnophis elegans) and THRA = Plains Garter Snake $($ Thamnophis radix) 
Appendix 1 (cont.). Characteristics of sites surveyed for colonial nesting birds, Bureau of Land Management, Lewistown District, June - July, 1996.

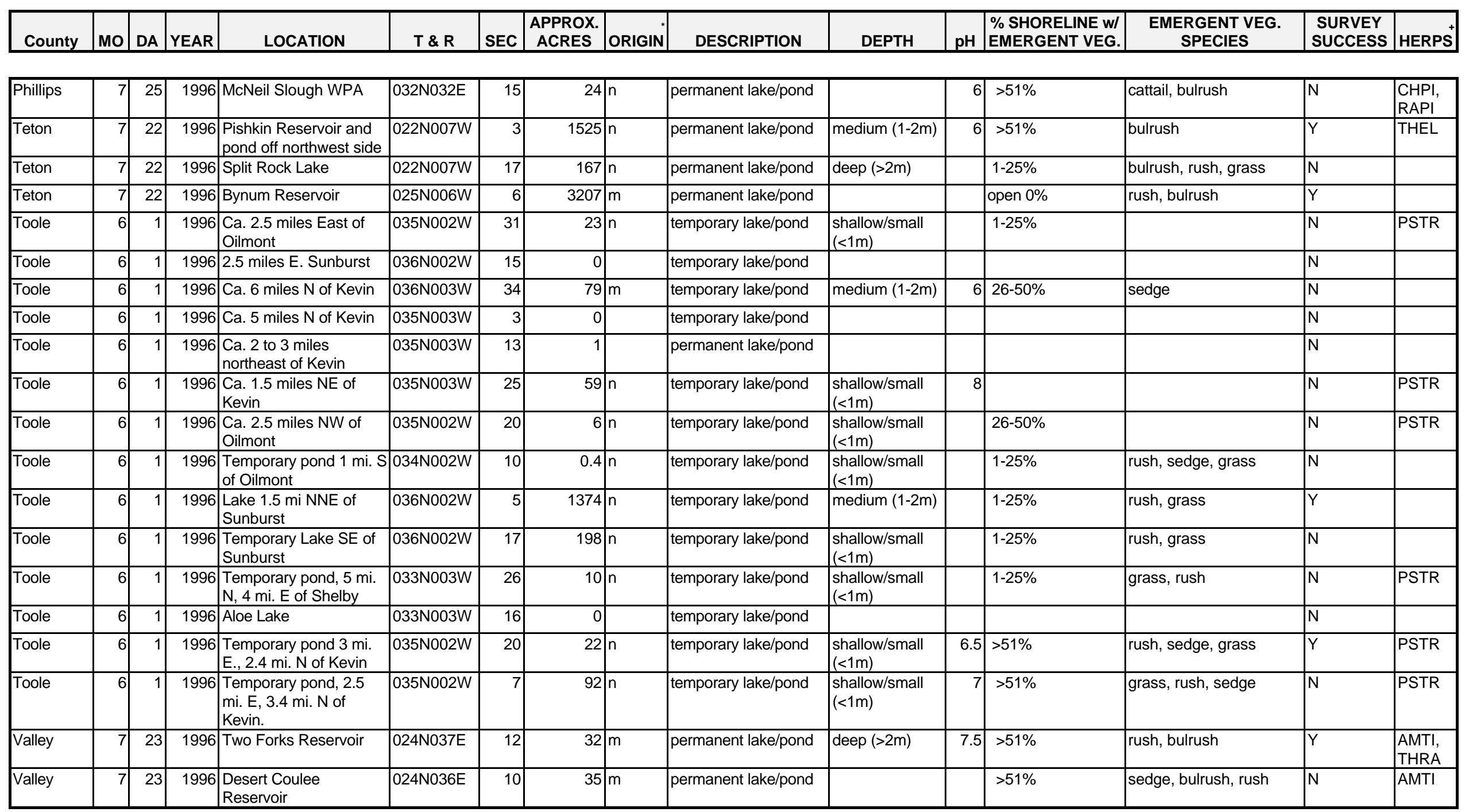

$\mathrm{n}=$ natural, $\mathrm{m}=$ man-made

AMTI $=$ Tiger Salamander (Ambystoma tigrinum), CHPI $=$ Painted Turtle $($ Chrysemys picta $)$, PSTR $=$ Western Chorus Frog $($ Pseudacris triseriata $), \mathrm{RAPI}=$ Northern Leopard Frog $($ Rana pipiens $)$,

$\mathrm{SCBO}=$ Plains Spadefoot (Scaphiopus bombifrons), THEL = Western Terrestrial Garter Snake (Thamnophis elegans) and THRA = Plains Garter Snake $($ Thamnophis radix) 
Appendix 1 (cont.). Characteristics of sites surveyed for colonial nesting birds, Bureau of Land Management, Lewistown District, June - July, 1996.

\begin{tabular}{|c|c|c|c|c|c|c|c|c|c|c|c|c|c|c|c|}
\hline County & Mo & DA & YEAR & LOCATION & $T \& R$ & SEC & $\begin{array}{c}\text { APPROX. } \\
\text { ACRES }\end{array}$ & ORIGIN & DESCRIPTION & DEPTH & pH & $\begin{array}{l}\% \text { SHORELINE w/ } \\
\text { EMERGENT VEG. }\end{array}$ & $\begin{array}{l}\text { EMERGENT VEG. } \\
\text { SPECIES }\end{array}$ & \begin{tabular}{|l|} 
SURVEY \\
SUCCESS \\
\end{tabular} & HERPS ${ }^{+}$ \\
\hline
\end{tabular}

\begin{tabular}{|c|c|c|c|c|c|c|c|c|c|c|c|c|c|c|c|}
\hline Valley & 7 & 23 & 1996 & $\begin{array}{l}\text { Hard Pan Creek } \\
\text { Reservoir }\end{array}$ & 025N036E & 27 & & $m$ & temporary lake/pond & & & & & $\mathrm{N}$ & \\
\hline Valley & 7 & 23 & 1996 & Halfpint Reservoir & 025N036E & 31 & 34 & $m$ & permanent lake/pond & & 7 & $26-50 \%$ & sedge, rush, bulrush & $N$ & PSTR \\
\hline Valley & 7 & 23 & 1996 & $\begin{array}{l}\text { Triple Crossing } \\
\text { Reservoir }\end{array}$ & 026N036E & 29 & 0 & $m$ & temporary lake/pond & & & & & $\mathrm{N}$ & \\
\hline Valley & 7 & 23 & 1996 & $\begin{array}{l}\text { Pearson Detention } \\
\text { Reservoir }\end{array}$ & 025N038E & 4 & 0 & $m$ & temporary lake/pond & & & & & $\mathrm{N}$ & \\
\hline Valley & 7 & 23 & 1996 & $\begin{array}{l}\text { Collins Detention } \\
\text { Reservoir } \\
\end{array}$ & 025N037E & 25 & 0.2 & $m$ & temporary lake/pond & & & & & $\mathrm{N}$ & \\
\hline Valley & 7 & 23 & 1996 & $\begin{array}{l}\text { Willow Creek Flat } \\
\text { Reservoir }\end{array}$ & 026N039E & 29 & 0 & $m$ & temporary lake/pond & & & & & $\mathrm{N}$ & \\
\hline Valley & 7 & 23 & 1996 & $\begin{array}{l}\text { Target Detention } \\
\text { Reservoir } \\
\end{array}$ & 025N038E & 11 & 0 & $m$ & temporary lake/pond & & & & & $\mathrm{N}$ & \\
\hline Valley & 7 & 23 & 1996 & $\begin{array}{l}\text { Bomber Detention } \\
\text { Diversion Reservoir }\end{array}$ & 025N038E & 15 & 0 & $m$ & temporary lake/pond & & & & & $\mathrm{N}$ & \\
\hline Valley & 7 & 23 & 1996 & Lori Detention Reservoir & 025N038E & 21 & 0 & $m$ & temporary lake/pond & & & & & $\mathrm{N}$ & \\
\hline Valley & 7 & 23 & 1996 & UL Reservoir & 025N035E & 1 & 0 & $m$ & temporary lake/pond & & & & & $\mathrm{N}$ & \\
\hline Valley & 7 & 23 & 1996 & Amambide Reservoir & 026N036E & 1 & 41 & $m$ & permanent lake/pond & & & open $0 \%$ & & $\mathrm{~N}$ & \\
\hline Valley & 7 & 23 & 1996 & $\begin{array}{l}\text { Gutshot Detention } \\
\text { Reservoir }\end{array}$ & 026N037E & 34 & 1 & $m$ & temporary lake/pond & $\begin{array}{l}\text { shallow/small } \\
(<1 \mathrm{~m})\end{array}$ & & $1-25 \%$ & sedge, bulrush & $\mathrm{N}$ & \\
\hline Valley & 7 & 23 & 1996 & $\begin{array}{l}\text { TC Drop Dam } \\
\text { Reservoir } \\
\end{array}$ & 026N037E & 30 & 0 & $m$ & temporary lake/pond & & & & & $\mathrm{N}$ & \\
\hline Valley & 7 & 23 & 1996 & $\begin{array}{l}\text { Mahan and Hoyt } \\
\text { Reservoir }\end{array}$ & 028N039E & 18 & 175 & $n$ & permanent lake/pond & & & $>51 \%$ & bulrush, cattail & $\mathrm{N}$ & \\
\hline Valley & 7 & 24 & 1996 & Ward Reservoir & 034N039E & 28 & 31 & $m$ & permanent lake/pond & deep (>2m) & 6 & $>51 \%$ & cattail, polygonum & $\mathrm{Y}$ & $\begin{array}{l}\text { CHPI, } \\
\text { RAPI }\end{array}$ \\
\hline Valley & 7 & 24 & 1996 & VR-2 Reservoir & 028N036E & 23 & 184 & $m$ & permanent lake/pond & & & $1-25 \%$ & polygonum & $N$ & \\
\hline Valley & 7 & 24 & 1996 & Coal Bank Reservoir & 028N035E & 29 & 79 & $m$ & permanent lake/pond & deep (>2m) & & $1-25 \%$ & polygonum, grass, rush & $\mathrm{N}$ & \\
\hline Valley & 7 & 24 & 1996 & Jim Reservoir & 026N036E & 3 & 82 & $m$ & permanent lake/pond & deep $(>2 m)$ & & open $0 \%$ & & $\mathrm{~N}$ & \\
\hline Valley & 7 & 24 & 1996 & Grubb Reservoir & 027N037E & 35 & 229 & $m$ & permanent lake/pond & & & open $0 \%$ & willow & $\mathrm{N}$ & \\
\hline
\end{tabular}

$\mathrm{n}=$ natural, $\mathrm{m}=$ man-made

AMTI $=$ Tiger Salamander (Ambystoma tigrinum), CHPI $=$ Painted Turtle $($ Chrysemys picta $)$, PSTR $=$ Western Chorus Frog $($ Pseudacris triseriata $)$, RAPI $=$ Northern Leopard Frog $($ Rana pipiens $)$,

$\mathrm{SCBO}=$ Plains Spadefoot (Scaphiopus bombifrons), THEL = Western Terrestrial Garter Snake (Thamnophis elegans) and THRA = Plains Garter Snake (Thamnophis radix) 
A P P E N D I X 2

\title{
Maps of Observations of TES Colonial Nesting Birds*, Bureau of Land Management, Lewistown District, June - July, 1996.
}

\author{
1. Black-crowned Night Heron \\ 2. Common Tern \\ 3. Forster's Tern \\ 4. Black Tern
}

Since no additional Black-necked Stilt colonies were located in 1996, a map is not provided here. (see Reichel 1996 for a map of occurrences). 
Observations of Black-crowned Night-Heron on the Lewistown District, BLM

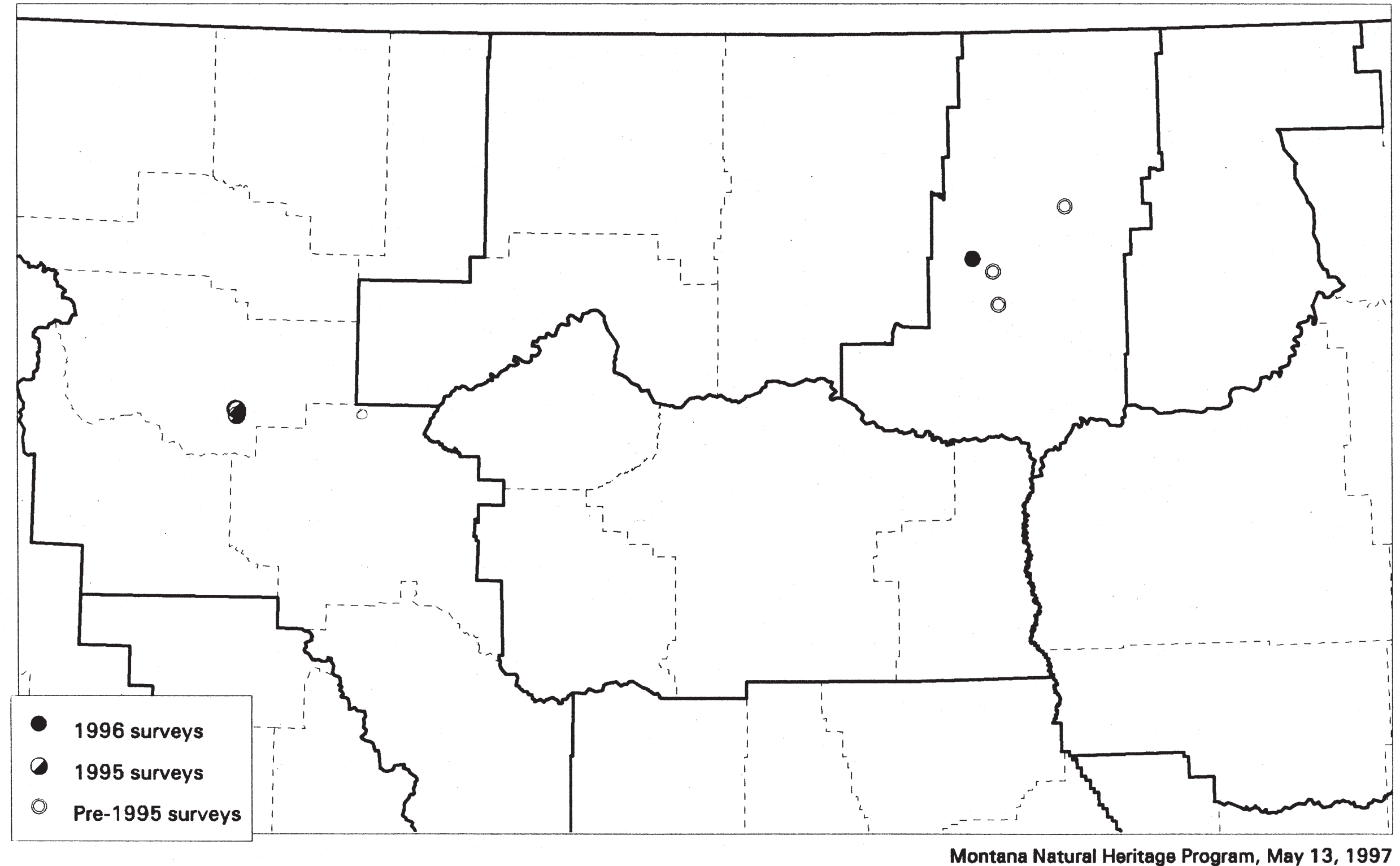


Observations of Common Tern on the Lewistown District, BLM

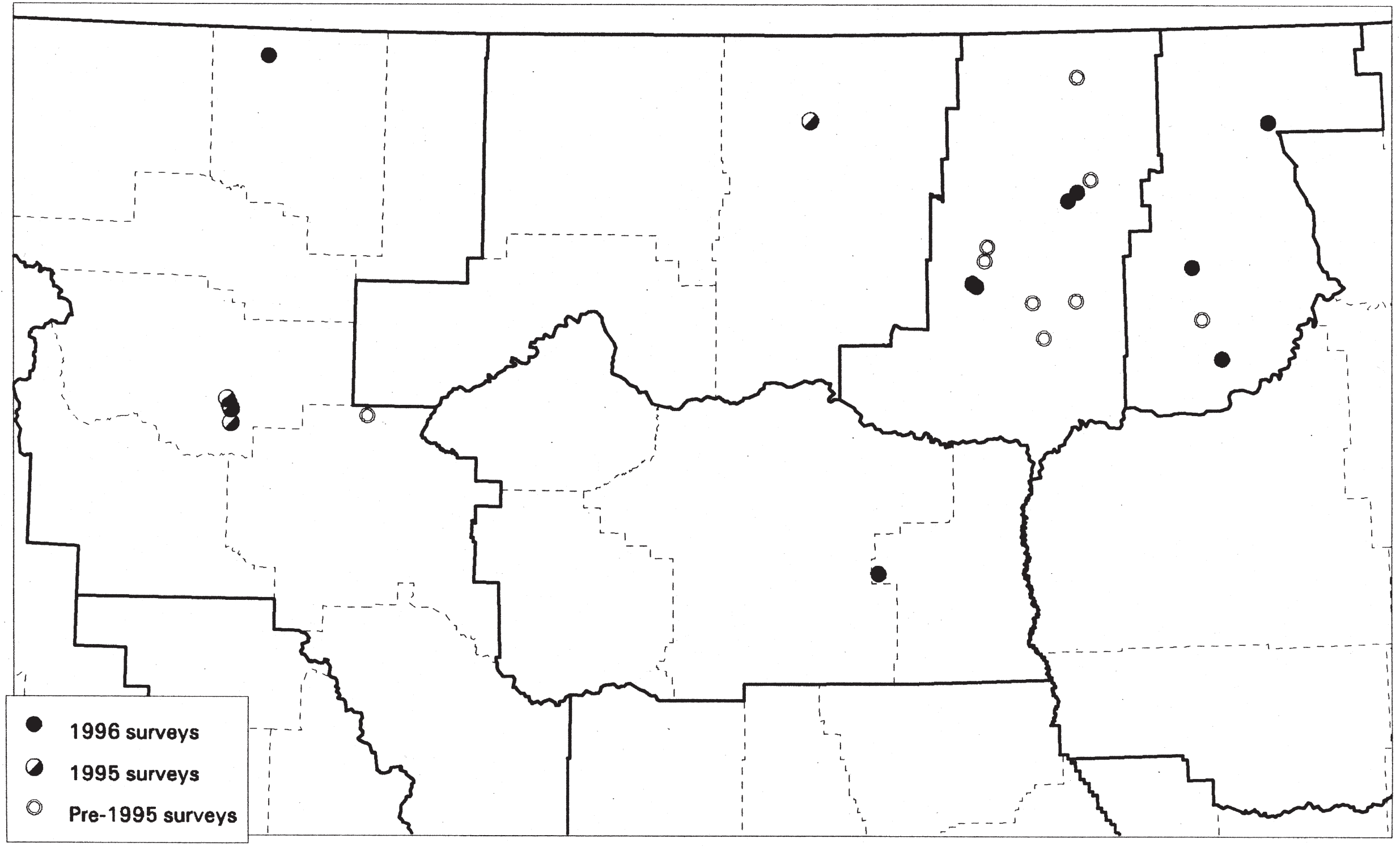

Montana Natural Heritage Program, May 13, 1997 
Observations of Black Tern on the Lewistown District, BLM

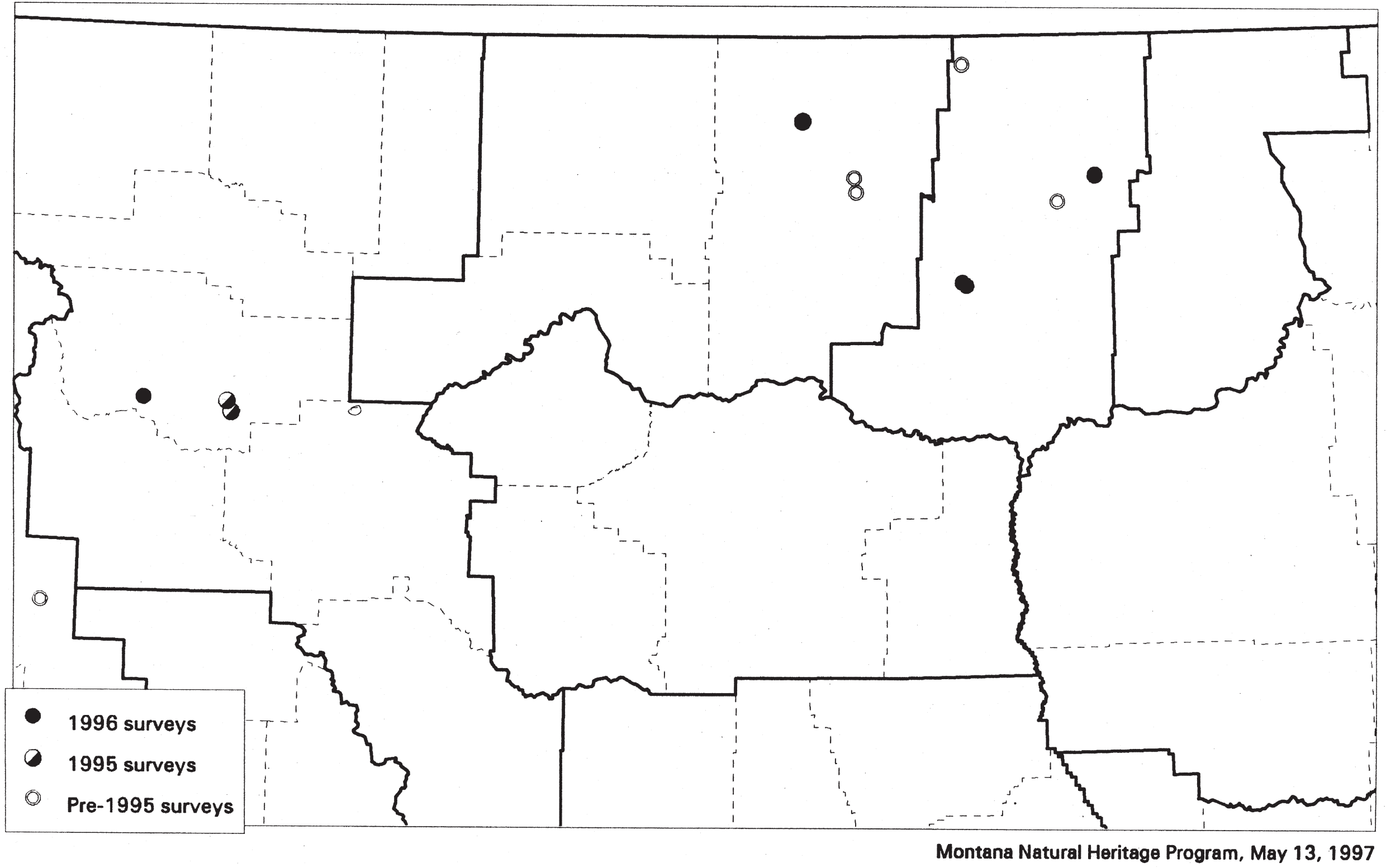


Observations of Forster's Tern on the Lewistown District, BLM

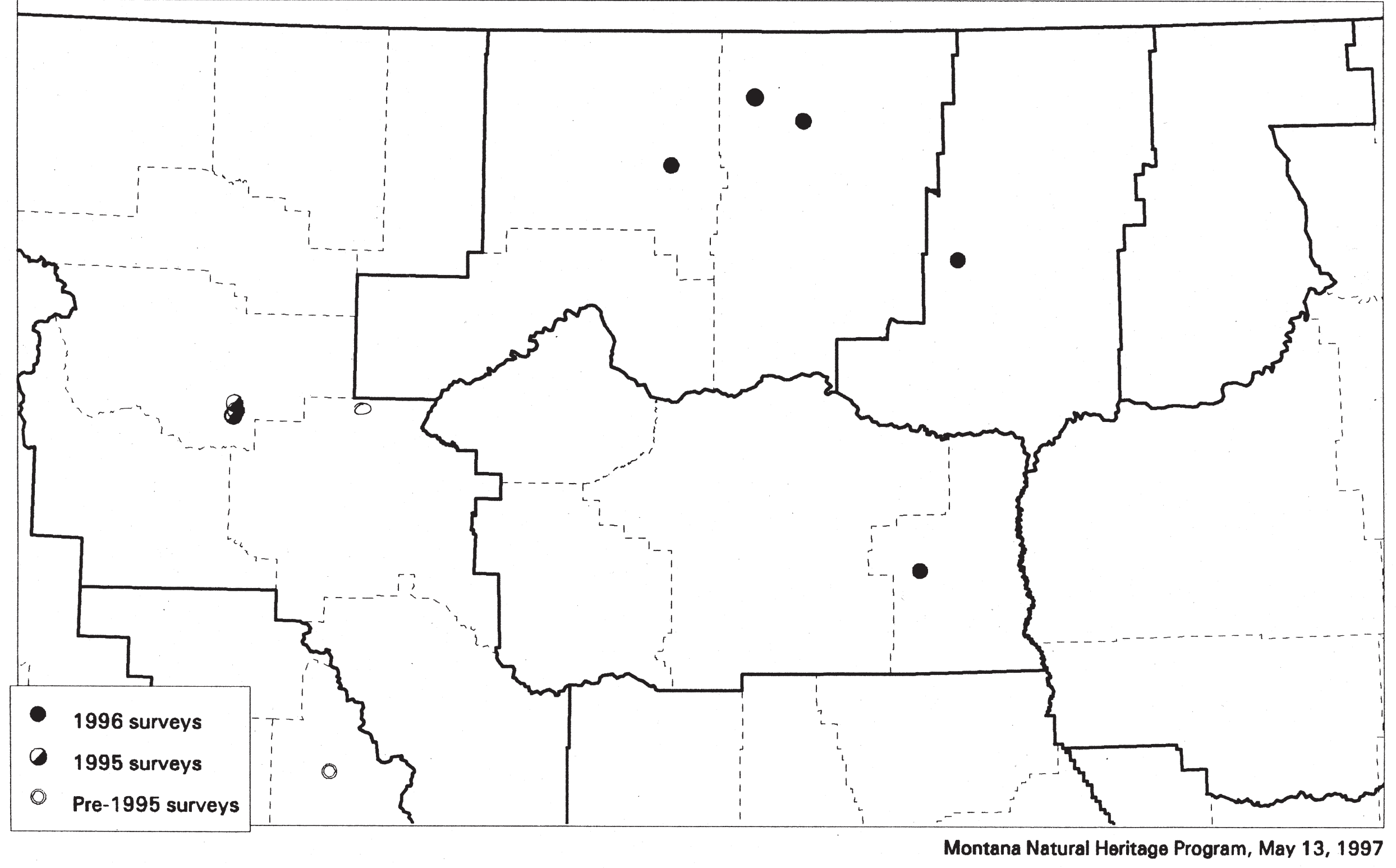

